\title{
Achieving Service innovation Through Market Orientation: The Role of Relationship Marketing and Knowledge Management
}

\author{
Asad Ullah ${ }^{1}$, Mansoora Ahmed ${ }^{2}$, Dmitry V. Zhukov ${ }^{3}$ \\ ${ }^{1,2,3}$ School of Management, Wuhan University of Technology, Wuhan, P.R.China, 430070 \\ Email (corresponding author): asadecon@yahoo.com
}

\begin{abstract}
Market orientation is a widely discussed concept in marketing literature while relationship marketing has emerged as an important paradigm over the past decade. Research has shown the significance of relationship marketing for increased sales and enhanced organizational performance. On the other hand, knowledge management is also an important agenda for organizations. Prevalent approach of service dominant logic has raised the interest of researchers in studying service as science. Both manufacturing industry and service industry rely on service innovations for success and competitive advantage. This paper theoretically analyzes the role of market orientation, relationship marketing and knowledge management and proposes a theoretical framework for their combined effect on service innovation. The framework is proposed for researchers to conduct further empirical studies in order to test its validity in practical work environment.
\end{abstract}

Keywords: Relationship Marketing, Knowledge Management, Service Innovation, Market Orientation.

\section{Introduction}

Market orientation is described by Kohli and Jaworski (1990) in three major constructs; intelligence generation, intelligence dissemination and responsiveness. The research on market orientation in service sector is very rare. Although, this area received less attention, this does not mean that market orientation in manufacturing firms is more important than in services firms (Kirsa et.al. 2005). Though there have been less studies about market orientation concept within service sectors, Kumar purposed that there is a direct relationship between market orientation and organizational performance within large service firms, especially within the health care sector. Change is a universal truth and a precondition for innovation which is based on the process of incorporating changes to produce new and better services. Innovation is the commercialization of an idea, practice, activity, features or object that is perceived as new to an individual, organization, or any other unit of adoption (Fruhling, 2007; Hsu, 2006; Damanpour, 1992). Studies have indicated that product innovation, service innovation, process innovation, marketing innovation and administrative innovation are the most widely studied innovation capabilities (Lin, 2010).

Service innovation is the process of developing new services that will be perceived as new (never seen before), as well as those improvements which are useful to customers (Flint et.al. 2010; Grant, 1991). Due to heterogeneous and fuzzy nature of services, short term transactional approach does not suits service sector. A strong long term relationship with customer aids service firms to understand the customer needs and wants, which further facilitates in service innovation process. Panesar and Markeset (2008) proposed that that market needs and customer initiatives are the most important service innovation process drivers, and the utmost imperative notion for service innovation is customer's feedback. For optimized utilization of the knowledge gathered from customers construct of knowledge management must be incorporated within the organization. Bassi (1997) defined knowledge management as the process of creating, capturing and using knowledge to enhance organizational performance. 


\section{Asad Ullah, Mansoora Ahmed, Dmitry V. Zhukov \\ Achieving Service innovation Through Market Orientation: The Role of Relationship Marketing and Knowledge \\ Management}

This research is an extension in existing literature on the relationship between market orientation and service innovation. The marketing literature identifies that there is a correlation between market orientation and service innovation. However, the mechanism of how it works i.e. how market oriented service sector firms can be innovative remains unexplored. In today's rapidly changing environment innovation is vital for survival of any business. Laforet and Tann (2006) recognized that innovating new products is the main reason behind surviving and thriving of many small and medium-sized British firms. So we may claim that firms which innovate successfully will maximize their opportunities of prosperity and survival (De Jong et.al. 2004). This study with moderating effect of relationship marketing and knowledge management provides a conceptual frame work to how market oriented service sector firms may achieve the ultimate target of service innovation by utilizing knowledge management framework. This conceptual model may be tested empirically and may also act as a base for future researches in the areas of service Innovation and market orientation.

\section{Literature review}

\subsection{Market Orientation}

Initially, market orientation was considered to be the implementation of the "marketing concept" as opposed to the sales concept where the ultimate goal was to produce products without getting feedback from the customers. Marketoriented organizations try to understand customers' expressed and latent needs, and develop solution to those needs through their offerings (Kohli, 1990; Narver et.al. 1990). Market orientation assists a firm to predict, respond, and take advantage of environmental changes leading to better performance. MO is associated with organizational performance and organizational commitment as well as return on assets (Narver et.al. 1990).

Information gathering and diffusion of information all over the organization puts all the departments in the organization on the table for interdepartmental coordination. That coordination reduces the chance of failure. Through understanding customer needs by gathering information, firms manage their relationship with the environment to maximize performance. Degree of difference in firm resources gives rise to superior strategy and performance (Barney, 1991; Porter, 1991). Prahalad and Hamel (1990) described core competencies as the collective learning of an organization and according to Narver and Slater (1990), such behaviors can be strengthened by developing a learning culture in an organization. Organization's performance is considered to be an outcome of MO. MO culture in an organization strengthen core competencies in an organization and team spirit can enhance organizational performance (Aviv Shoham et.al).

There are five different schools of thought that describes MO in their distinctive concepts of market orientation.

- Decision making perspective (Shapiro, 1988)

- Market intelligence perspective (Kohli, 1990)

- Culturally based behavioral perspective (Narver et.al. 1990)

- Strategic perspective (Ruekert et.al. 1992)

- Customer Oriented perspective (Deshpande, 1993)

\subsubsection{Decision making perspective}

Shapiro presented decision making perspective of market orientation (Shapiro, 1988). This perspective considers market orientation as an organizational decision making process. Decision making perspective considers it the duty of top management in an organization to share information inter-departmentally throughout the organization and encourage open decision making. In other words, it emphasizes on open decision making among divisional and functional departments.

There are three components of decision making perspective(1) Information on all important buying influences every corporate function (2) Strategic and tactical decisions should be made inter-functionally and inter-divisionally (3) Divisions and functions make well-coordinated decisions and execute them with a sense of commitment.

As per the components of this perspective we can state that understanding the customers i.e. understanding current and future needs of customers is main focus of this theme. Knowing competitors gathering information about customers and competitors and sharing that information all over the organization. Only after getting enough information, 


\section{Asad Ullah, Mansoora Ahmed, Dmitry V. Zhukov \\ Achieving Service innovation Through Market Orientation: The Role of Relationship Marketing and Knowledge \\ Management}

functions and divisions may be able to make better and well informed strategic and tactical decisions. Both the functions and divisions should listen to each other and must be willing for an open decision making process. Interdepartmental harmonization is important as it is the key of success for any decision and in most of the cases, the opposite is a major cause of failure.

\subsubsection{Market intelligence perspective}

According to this perspective "market orientation is the organization-wide generation of market intelligence pertaining to current and future customer needs, dissemination of the intelligence across departments, and organization- wide responsiveness to it” (Kohli, 1990). Kohli and Jaworski (1993) explained MO through an Activity based perspective. With an operationalized approach. There are three constructs of Kohli and Jaworski’s (1990) definition of MO.

(1) Intelligence generation

(2) Intelligence dissemination

(3) Responsiveness.

The first component projected here is intelligence generation i.e. gathering information about customers, their needs and wants and knowing the competitor what offerings competitor have and how they affect consumers. This includes what are present as well as future needs of the consumer. Mechanism of information generation is not restricted to formal means. It also includes information gathering from informal means as well. All this Information is obtained by all functional departments. The second construct is Intelligence dissemination. All the gathered information about customers and competitors must be diffused among entire organization. This dissemination of market intelligence is important because it provides a shared basis for combined actions by the different departments (Kohli, 1990). Third construct here is responsiveness. All the departments in an organization should be responsive towards this information. According to Kohli and Jaworski (1990), all departments need to be responsive and this can take the form of selecting the appropriate target markets, designing, producing, promoting and distributing products that meet current and anticipated needs. According to this perspective of MO, marketing is not the responsibility of a single department rather it is the function of all the departments of an organization. All the departments are involved from start to the end i.e. from information gathering to diffusion of information to a suitable response to that information.

\subsubsection{Culturally based behavioral perspective}

Narver and Slater (1990) defined market orientation as "the organizational culture that most effectively and efficiently creates the necessary behaviors for the creation of superior value for buyers and thus, continues superior performance for the business".

Narver and Slater (1990) also discussed customer orientation, competitors and inter-functional coordination but with a behavioral perspective. Components of Narver and Slater's definition of Market orientation are

(1) Customer orientation

(2) Competitor orientation

(3) Inter-functional coordination

The first component of customer orientation requires understanding of the customer. The rationale here is to create value for the customers which can be achieved by understanding what the needs of the customers are, again here the focus is on both present and future needs. Information of competitor is equally important as customer information. According to Narver and Slater (1990) competitor orientation is parallel to customer orientation.

It is of key importance to know your competitor's present and future plans well. Their strengths and weaknesses, their advantages and capabilities so the organization may prepare itself for the competition as well. Inter-functional coordination is important for the coordinated use of company resources and distribution of information throughout the organization. Narver and Slater (1990) proposed that this must be cultured by focusing on the advantages of different areas in cooperating closely with each other. All the departments in an organization must understand and respect needs of each other as this will bring different ideas on the table and with that culture an organization can create value for its customers. 


\section{Asad Ullah, Mansoora Ahmed, Dmitry V. Zhukov \\ Achieving Service innovation Through Market Orientation: The Role of Relationship Marketing and Knowledge \\ Management}

\subsubsection{Strategic focus perspective}

The level of market orientation in a business unit is the degree to which the business unit obtains and uses information from customers, develops a strategy which will meet customer needs, and implements that strategy by being responsive to customer needs and wants (Ruekert et.al. 1992). This approach of market orientation focuses on single business unit. Information is gathered from external environment i.e. customers and resources are allocated to the goals and objectives set as a response to the information provided with by customer. Designing a plan with focus on customer centric strategy in order to fulfill customer needs and wants. This is a narrowed concept as focus is on strategy making rather than other stakeholders.

\subsubsection{Customer orientation perspective}

Customer orientation is the set of beliefs that puts the customer's interest first, while not excluding those of all other stakeholders such as owners, managers, and employees, in order to develop a long-term profitable enterprise (Deshpande, 1993). Deshpande (1993) excluded competitors completely from market orientation concept and instead stressed on inter-departmental coordination. This perspective is a narrowed perspective as focus is on customer oriented approach only competitors have been excluded completely in this perspective.

\subsection{Service Innovation}

Innovation is anything which might be a new idea, practice, activity, feature of a service that is perceived as new to an individual, organization, or any other unit of adoption (Fruhling, 2007; Hsu, 2006; Damanpour, 1992). Weerawardena (2006) explained innovation as the adjustment of product, service, process, organizational systems, and marketing systems so as to create and enhance customer relationship through upgrading customer value. Literature has identified two major aspects of innovation as degree of innovation and scope of innovation.

The degree of innovation consists of two further types; radical innovation and incremental innovation. Radical innovation is the creation of a totally new product, new service, new market, or new technology (Green et.al. 1995). Where as in incremental innovation the general structure of the product, service or system remains the same, but it changes through the addition or substitution of characteristics to improve the systems performance. Damanpour and Evan (1984) distinguished innovation concept in technical and administrative domains. Technical innovation contains products, services, marketing as well as technology used to create products or services which are directly related to the organizations core processes (Damanpour et.al. 1984; Daft, 1982). On the other hand, administrative innovation is related to the administrative activities and organizational structure which are indirectly connected to the core tasks within the organization (Damanpour et.al. 1984).

Narver (2004) emphasized that focus on customer needs, wants and internal process of the organization is the route for a business to be Innovative. According to him successful business must be innovative in its nature for the following reasons: (1) to learn more and follow customers' needs and wants, (2) to conduct successfully the process of developing new products or services that address those needs and wants and (3) to help in executing internal activities and processes that enhance product development process and understanding of customers' needs. It is very difficult to analyze service Innovation mainly due to the heterogeneous service characteristics (Gallouj, 1997). De Jong and Vermeulen (2003) elaborated that service innovation is not only about newness. It also includes other scopes like after sales services, delivering systems and the relationships between buyer and sellers. Verma et al. (2008) explained service innovation as the newness in the service concept, processes, customer knowledge and experience, technology, business model, employee experiences and business procedures.

\subsection{Relationship Marketing}

Relationship Marketing concept have roots in service firms. It was initially identified in banking sector with the name of relationship banking. Relationship banking is defined as "attracting, maintaining, and enhancing client relationships" (Berry, 1983). Berry (2005) further took the relational approach in a conference proceeding in services marketing with the American Marketing Association where the term "Relationship Marketing” was first used to describe the relational approach in services marketing. Coviello (1997) categorized marketing into transactional marketing and relationship marketing. According to him relationship marketing includes database marketing, interaction marketing and network marketing. 


\section{Asad Ullah, Mansoora Ahmed, Dmitry V. Zhukov \\ Achieving Service innovation Through Market Orientation: The Role of Relationship Marketing and Knowledge \\ Management}

The transactional approach in services marketing was challenged for its deviation from the rapidly evolving environment in the services industry. Gummesson (1997) criticized that the short term nature of transactional marketing did not apply to services marketing and industrial marketing. He proclaimed that experts in services market and industrial marketing emphasized long term, interactive relationship between buyers and sellers. Trust and commitment are essential for a relationship (Morgan et.al. 1994). In an exchange process, they form the basis for a reliable and enduring relationship.

Gronroos, (1995; 1994) and Storbacka, Strandvik (1994) emphasized economic importance of relationship marketing. According to them economic benefit exists in building and maintaining relationship with customers because of the higher costs in creating new customers than retaining existing ones. Gummesson (1997), Gronroos (1995; 1994) explained that relationship marketing maintains a long-term relationship with the customer while transactional marketing is transactional and short-term in nature. In relationship marketing, customers tended to be less calculated. In addition, relationship marketing focuses on the customer, attended to their satisfaction, and maintained quality interactions with the customers. On the other hand, transactional marketing is based on gimmicks, focused on single transaction and ignored quality of interactions with the customers, and was market share oriented (Gronroos, 1994).

Relationship marketing concept treats customer as partner and emphasize on building networks with customers. Gronroos (1996) suggested that relationship played a strategic and tactical role in networking between business partners. Stone and Mason (1997) demonstrated the strategic nature of relationship in marketing with the close-knitted networking and interdependencies of business partners participating in the processes of system selling, just-in-time, and quick response system. Morgan and Hunt (1994) explained the strategic value of organizational resources in obtaining a relationship-based competitive advantage. Li and Nicholls (2000) opposed that the mutually cooperative interaction in an exchange process was a strategic choice. Gummesson (1997) offered a 3Rs approach within an operational perspective that defined relationship marketing as "relationships, networks and interaction".

\subsection{Knowledge Management}

Knowledge management is the process of creating, capturing and using knowledge to enhance organizational performance (Bassi, 1997). Rumizen (2001) explained knowledge management as how an organization identify, capture creates and acquire, knowledge. Organization can learn from past experiences stored in corporate memory systems (Peter, 1990). Nonaka and Takeuchi (1995) studied how knowledge is produced, used and diffused within organization and how such knowledge contributed to the diffusion of innovation. They defined knowledge as "justified true belief" and purposed that there are three stages to understand knowledge

The stages to understand knowledge by Nonaka and Takeuchi (1995) are;

- Know how

- Accumulated facts

They have divided knowledge on basis of accessibility into two categories tacit and explicit knowledge (Nonaka et.al. 1995).

Tacit Knowledge cannot be expressed and is not codified. Michael Polanyi said "We know more than we can tell". Explicit Knowledge refers to formal and systematic knowledge and Nonaka (1995) offers product specifications, scientific formulas and computer programs as examples; a knowledge that has been expressed and captured in form of text, tables and so on). Knowledge management refers to a systematic and organizationally specified process for acquiring, organizing and communicating both tacit and explicit knowledge of employees so that other employees may make use of it to be more effective and productive in their work (Alavi et.al. 1999).

Morris and Empson (1998) divided knowledge Management into four stages.

1) Knowledge capture and creation

2) Knowledge organization and Retention

3) Knowledge Dissemination

4) Knowledge Utilization

These Four identified stages are followed in an organization in order to achieve the target of knowledge management. First knowledge is captured from external sources like market. It includes knowledge gathered from customers through feedback and suggestions etc. Knowledge creation can also be internal knowledge gathering which is knowledge 


\section{Asad Ullah, Mansoora Ahmed, Dmitry V. Zhukov \\ Achieving Service innovation Through Market Orientation: The Role of Relationship Marketing and Knowledge \\ Management}

creation and knowledge gathering within an organization. Second step in knowledge management is knowledge organization and retention which includes storing of knowledge in databases and making it accessible for the use of entire organization. This step is followed by knowledge sharing which can be described as either push or pull. Knowledge Pull is when the knowledge worker actively seeks out knowledge sources (e.g. library search, seeking out an expert, collaborating with a co-worker etc.), while knowledge push is when knowledge is "pushed onto" the user (e.g. newsletters, unsolicited publications, etc.). Last step of the process is the use of that knowledge which is termed as knowledge utilization.

\subsection{Market Orientation and Service Innovation}

The relationship between market orientation and innovation has received particular attention (Matear et.al. 2008) Research has been conducted in past on the extent to which market orientation contributes to innovation (Matear et.al. 2008). A positive relationship has been identified between market orientation and innovation (Gatignon et.al. 1997; Atuahene-Gima et.al. 1996; Lukas et.al. 2000). Jaworski and Kohli (1993) suggested that, since «a market orientation essentially involves doing something new or different in response to market conditions, it may be viewed as a form of innovative behavior». They also explained that a greater degree of market orientation will lead to a greater level of superior performance based on innovation (Kohli, 1990; Jaworski et.al. 1993). For example, if an organization is aware of competitor's activities before the other competitors, and can follow their immediate innovation or develop new service offerings in response to the competitors they can catch up or even excel in the market. Innovation speed in the models of market orientation must not be overlooked (Lukas et.al. 2000). According to Slater (1997) "successful innovation is the product of a market oriented culture coupled with entrepreneurial values". Jaworski and Kohli (1993) Purposed that it is not possible to believe that innovation is absent in models of market orientation. In contrast to Jaworski and Kohli (1993), Gatignon and Xureb (2000) suggested that the relationship between market orientation and innovation is an ongoing process which repeats itself again and again, so that market orientation does not make a contribution directly to firm's performance and its contribution to innovation is adequate to be valuable. On the other hand, most of this research did not inspect if market orientation makes a contribution to firm performance, as well as its contribution to innovation (Matear et.al. 2008).

A high positive association between the levels of innovativeness in firm's culture and innovation capacity is identified by Hurley and Hult (1998). According to them market orientation researches should directly integrate innovation concepts. Panesar and Markeset (2008) purposed that that market needs and customer initiatives are the most important service innovation process drivers, and the utmost imperative notion for service innovation is customer's feedback. In addition to that, service innovation (either creating new services or improving the existing services) is a result of interaction. Kuusisto and Meyer (2003); Gronroos (2000), also suggested that the key points for service innovation and performance optimization are:

1) Generation of knowledge

2) Joint problem solving practices

Knowledge generation from customers about their needs, wants, and preferences and joint effort by organization and its clients to resolve problems leads to performance optimization of the business and eventually the ultimate goal of service innovation can be achieved. According to Kandampully (2002) combined influence of technology, knowledge and networks energize innovation in service firms. Gronroos (2000) concluded that 'service innovation process is complex because it depends heavily upon management and coordination for a large number of inter-organizational activities and interactions between different managerial levels, as well as service innovation process depends heavily on deliberated planning and detailed understanding of customers' needs, wants, and preferences’.

\section{Research Propositions}

Kohli and Jaworski (1990) identified Intelligence Generation as first phase in Market orientation. Relationship marketing is defined as "relationships, networks and interaction" (Gummesson, 1997). These Networks and long term relationships with customers treat Customer as Partners and their opinion and feedback becomes vital for the organization. And more Interaction with customers helps in generating more knowledge about customer, needs and wants which is essential to design or innovate new services. Trust and commitment are essential for a relationship (Morgan et.al. 1994). In an exchange process, they form the basis for a reliable and enduring relationship. In 


\section{Asad Ullah, Mansoora Ahmed, Dmitry V. Zhukov \\ Achieving Service innovation Through Market Orientation: The Role of Relationship Marketing and Knowledge \\ Management}

relationship marketing as customer trusts the organization, they openly express their unbiased opinion and Information about their needs, wants and feelings to the organization. As Narver (2004) emphasized that focus on customer needs, wants and internal process of the organization is the route for a business to be innovative. So with optimized Information generation process service innovation can be achieved.

P1: When implemented with market orientation, relationship marketing will optimize intelligence generation to achieve service Innovation.

Knowledge management as suggested by Morris and Empson (1998), have knowledge dissemination as a phase in knowledge management process which allows us to claim that knowledge management if integrated with market orientation concept may maximize intelligence dissemination which is also second phase of market orientation process suggested by Kohli and Jaworski (1990).

P2: When implemented with market orientations, knowledge management will optimize intelligence dissemination to achieve service Innovation.

Knowledge management also has knowledge utilization as its last step which is identified as similar to "responsiveness" in market orientation (Kohli, 1990). So together knowledge management and market orientation leads to service innovation as a result of knowledge utilization for new service development or modification of existing services according to customer needs and wants. Similarly, knowledge about competitor's services and its utilization for designing improved or new services can also lead to service innovation.

P3: When implemented with market orientations knowledge management will optimize Information utilization to achieve service innovation.

\section{Methodology and Technological Route}

A literature based conceptual frame work is developed to show the relationship between market orientation and service innovation. In the conceptual frame work it is proposed that market oriented service firms can achieve service innovation as a result of combined moderating effect of relationship marketing and knowledge management as shown in Figure 1.

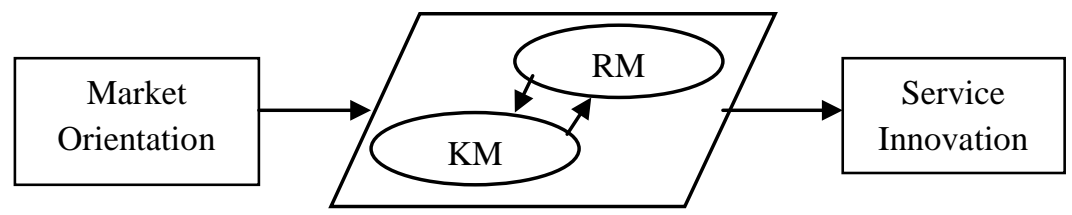

Figure 1: Conceptual Framework

Literature provides evidence that correlation exists between market orientation and service innovation. On the basis of existing literature on relationship marketing and knowledge management it is proposed that relationship marketing can act as a moderator between market orientation and service Innovation as it focuses on long-term relationship with customer and network building. If incorporated with market orientation, relationship marketing can optimize intelligence generation which is first phase of market orientation as described by Kohli and Jaworski (1990). Similarly knowledge management as suggested by Morris and Empson (1998) have knowledge dissemination as a phase in knowledge management process which allows us to claim that knowledge management if integrated with market orientation concept may maximize intelligence dissemination which is also second phase of market orientation process suggested by Kohli and Jaworski (1990). Knowledge management is also having knowledge utilization as its last step which is referred to as responsiveness in market orientation terminology. So together, knowledge management and market orientation leads to service innovation as a result of knowledge utilization. Knowledge built by market orientation through relationship marketing and that knowledge if shared organization wide through knowledge sharing, knowledge dissemination process will result in optimum usage of knowledge gathered from the customers and 
environment. Focus on customer needs and wants by using the knowledge gathered from the process of market orientation and development of new or redesigning of existing services will lead organization towards the ultimate goal of service innovation as shown in Figure 2.

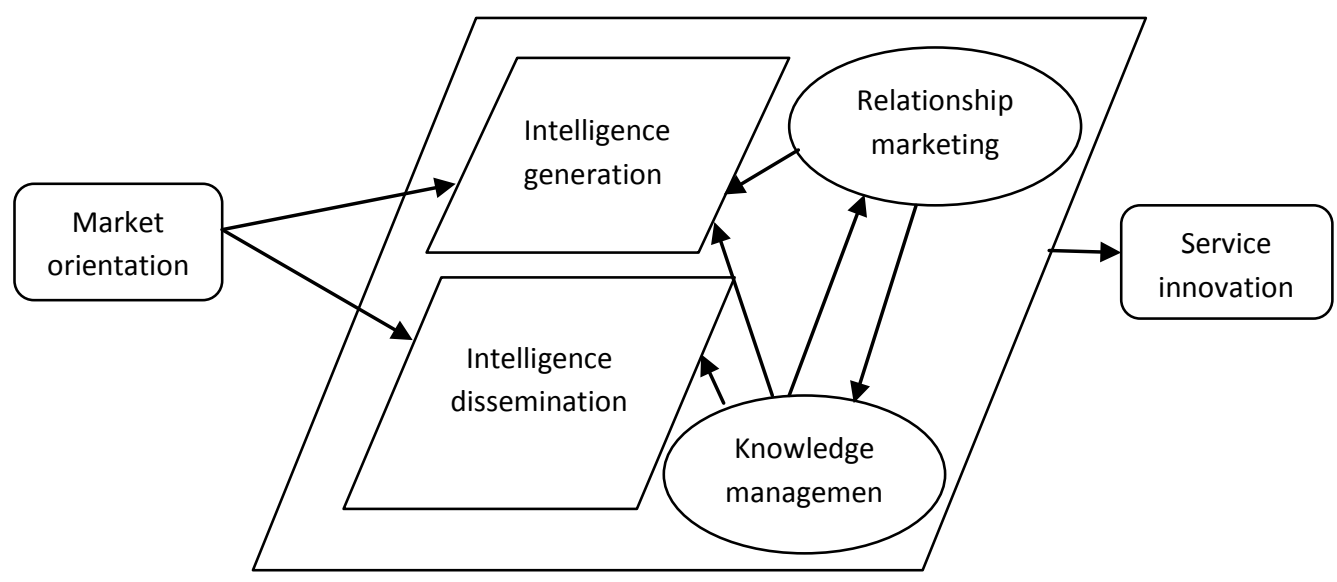

Figure 2: Theoretical framework for enhancing service innovation

\section{Conclusion}

In a present era of globalization and rapidly changing environment the combined role of relationship marketing (cooperation and collaboration) with knowledge management (capturing information \& sharing) gives strength to the implementation of service innovation through market orientation practices. If this system is developed and implemented in organizations, it will help to build strong culture of collecting and sharing knowledge that plays key role to enhance service innovation.

\section{References}

- $\quad$ Alavi, M., Leidner, D. Knowledge Management Systems: Issues, Challenges, and Benefits. Communications of the Association for Information Systems, 1999, 1, Article 7.

- Atuahene-Gima, K. Market orientation and innovation". Journal of Business Research, 1996, 35, 93103, Crossref

- Aviv Shoham, Gregory M. Rose and Fredric Kropp Market orientation and performance: a meta-analysis.

- Barney, J. B. Firm resources and sustained competitive advantage. Journal of Management, 1991, 17, 99120, $\underline{\text { Crossref }}$

- $\quad$ Bassi, L.J. Harnessing the power of intellectual capital. Training \& Development, 1997, 51(12), 25-30.

- $\quad$ Berry, L. L. Bank Marketing Priorities in the United States. European Journal of Marketing, 2005, 16(3), 513, Crossref

- Berry, L. L. Relationship Marketing. In L. L. Berry, G. L. Shostack \& G. D. Upah (Eds.), Emerging Perspectives on Services Marketing. Utah: American Marketing Association 1983, 25-28.

- Coviello, N. E., Brodie, R. J., \& Munro, H. J. Understanding Contemporary Marketing: Development of a Classification Scheme. Journal of Marketing Management, 1997, 13(6), 501-522, Crossref

- Daft, R.L. Bureaucratic versus non-bureaucratic structure and the process of innovation and change. Research in the Sociology of organizations, JAT Press, Greenwich, CT, 1982, 1, 66-129.

- $\quad$ Damanpour, F. (1992), "Organizational size and innovation", Organization Studies, Vol. 13 No. 3, pp. 375402, $\underline{\text { Crossref }}$

- $\quad$ Damanpour, F. and Evan, W.E. Organizational innovation and performance: the problem of organizational lag. Administrative Science Quarterly, 1984, 29(3), 392-409, Crossref

- Damanpour, F. Organizational innovation: a meta-analysis of effects of determinants and moderators. Academy of Management Journal, 1991, 34(3), 90-555, Crossref

- $\quad$ De Jong, J., Vermeulen, P. and Oshaughness, K. Effects of innovation in small firms". M\&O, 2004, 58(1), 2138. 
- De Jong, J.P. and Vermeulen, P.A. Organizing successful new service development: a literature review. Management Decision, 2003, 41(9), 58-844, Crossref

- $\quad$ Deshpande, R. (ed.) Developing a Market Orientation. Sage Publishing, Thousand Oaks, CA. 1993

- Flint, D.J., Larsson, E., Gammelgaard, B. and Mentzer, J.T. Logistics innovation: a customer value-oriented social process. Journal of Business Logistics, 2005, 26(1), 47-113, Crossref

- Fruhling, A.L. and Siau, K. Assessing organizational innovation capability and its effect on e-commerce initiatives. The Journal of Computer Information Systems, 2007, 48(1), 45-133.

- Gallouj, F. and Weinstein, O. Innovation in services. Research Policy, 1997, 26, 537-556, Crossref

- Gatignon, H. and Xuereb, J.M. Strategic orientation of the firm and new product performance". Journal of Marketing Research, 1997, 34(1), 77-90. Grant, R.M. The resource-based theory of competitive advantage: implications for strategic information." California Management Review, 1991, 33(3), 35-114.

- Green, S.G., Gavin, M.B. and Aiman-Smuth, L. Assessing a multidimensional measure of radical technological innovation. IEEE Transactions in Engineering Management, 1995, 42(3), 14-203, Crossref

- Gronroos, C. From Marketing Mix to Relationship Marketing: Towards a Paradigm Shift in Marketing. Management Decision, 1994, 32(2), 4-20, Crossref

- Gronroos, C. Relationship Marketing: Strategic and Tactical Implications. Management Decision, 1996, 34(3), 5-14, Crossref

- $\quad$ Gronroos, C. Service innovation and marketing, (2nd ed.).London: John Wiley. 2000

- Gummesson, E. The New Marketing - Developing Long Term Interactive Relationships. Long Range Planning, 1997, 20(4), 10-20, $\underline{\text { Crossref }}$

- Han, J.K., Kim, N. and Srivastava, R.K. Market orientation and organizational performance: Is innovation a missing link? Journal of Marketing, 1998, 62(4), 30-45, Crossref

- Hsu, L. L. The impact of industrial characteristics and organizational climate on KMS and BIP-Taiwan bioscience industry. The Journal of Computer Information System, 2006, 46(4), 8-17.

- Hurley, R.F. and Hult, G.T.M. Innovation, market orientation and organizational learning: An integration and empirical examination. Journal of Marketing, 1998, 62, 42-54, Crossref

- Jaworski, B. and Kohli, A.K. Market orientation: Antecedents and Consequences". Journal of Marketing, 1993, 57, 53-70. Kandampully, J. Innovation as the core competency of a service organization: the role of technology, knowledge and networks". European Journal of Innovation Management, 2002, 5(1), 18-26.

- Kirca, A., Jayachandran, S. and Bearden, W. Marketing orientation: A meta-Analytic review and assessment of its antecedents and impact on performance. Journal of Marketing, 2005, 69, 24-41, Crossref

- $\quad$ Kline, R. B. Principles and practice of structural equation modeling. New York: The Guilford press, 1998

- Kohli, A. and Jaworki, B.J. Market orientation: the construct, research propositions, and managerial implications. Journal of Marketing, 1990, 54, 1-18, Crossref

- Kuusisto, J. and Meyer, M. Insights into services and innovation in the knowledge intensive economy". Technology Review, 2003, 134.

- Lado, N. and Maydeu-Olivares, A. Exploring the link between market orientation and innovation in the European and US insurance markets. International Marketing Review, 2001, 18(2), 130-144, Crossref

- Laforet, S. and Tann, J. Innovative characteristics of small manufacturing firms. Journal of Small Business and Enterprise Development, 2006, 13(3), 80-363, Crossref

- $\quad$ Lin, R.J., Chen, R.H. and Chiu, K. Customer relationship management and innovation capability: an empirical study. Industrial Management and Data Systems, 2010, 100(1), 111-133, Crossref

- Lukas, B. and Ferrell, O.C. The effect of market orientation on product innovation". Journal of Academy of Marketing Science, 2000, 28(2), 47-239, Crossref

- Matear, S., Osborne, P.,Garrett,T. and Gray, B. How does market orientation contribute to service firm performance? European Journal of Marketing, 2002, 36(9/10), 1058-1075, Crossref

- Morgan, R. M., \& Hunt, S. D. The Commitment Trust Theory of Relationship Marketing. Journal of Marketing, 1994, 58(3), 20-38, Crossref

- Gronroos, C. Relationship Marketing: The Strategy Continuum. Journal of the Academy of Marketing Science, 1995, 23(4), 252-255, Crossref Crossref

- Storbacka, K., Strandvik, T., \& Gronroos, C. Managing Customer Relationship for Profit: The Dynamics of Relationship Quality. International Journal of Service Industry Management, 1994, 5(5), 21-38, Crossref

- Morris, T., Empson, L. Organization and expertise: an exploration of knowledge bases and the management of accounting and consulting firms. Accounting, Organization and Society, 1998, 23(5/6), 609-624, Crossref

- Narver, J. and S. Slater. 'The effect of a market orientation on business profitability', Journal of Marketing. 1990, Crossref

- Narver, J., Slater, S. and Maclachlan, D. Responsive and proactive market orientation and new product success. Journal of Product Innovation Management, 2004, 21, 334-347, Crossref 
- $\quad$ Nonaka, I., Takeuchi, H. The Knowledge-Creating Company: How Japanese Companies Create the Dynamics of Innovation? Oxford University Press, 1995.

- $\quad$ Panesar, S.S. and Markeset, T. Developing of a framework for industrial service innovation management and coordination. Journal of Quality in Maintenance Engineering, 2008, 14(2), 177-193, Crossref

- $\quad$ Peter M. Senge, The Fifth Discipline: The Art \& Practice of The Learning Organization. New York: Currency Doubleday, 1990

- Porter, M.E. Towards a Dynamic Theory of Strategy, Strategic Management Journal, 1991, 12, 95117, Crossref

- Prahalad, C. K. and Hamel, Gary. The Core Competence of the Corporation. Harvard Business Review, 1990, 68(3), 79-91.

- Ruekert, R. W. Developing a Market Orientation: An Organizational Strategy Perspective, International Journal of Research in Marketing, 1992, 9(3), pp. 225-245, Crossref

- $\quad$ Rumizen, M.C. The complete idiots guide to knowledge management. Alpha; 1 edition, 2001.

- $\quad$ Shapiro, B. What the hell is market-oriented? Harvard Business Review. 1988

- Slater, S. Developing a customer value-based theory of the firm". Journal of Academy of Marketing Science, 1997, 25, 67-162, Crossref

- Stone, R. N., \& Mason, J. B. Relationship Management: Strategic Marketing's Next Source of Competitive Advantage. Journal of Marketing Theory and Practice, 1997, 5(2), 8-19, Crossref

- Li, F., \& Nicholls, J. A. F. Transactional or Relationship Marketing: Determinants of Strategic Choices. Journal of Marketing Management, 2000, 16(5), 449-464, Crossref

- Verma, R., Anderson, C., Dixon, M., Enz, C.,Thompson, G. Victorino, L. Key elements in service innovation: insights for the hospitality industry". Cornell Hospitality Roundtable Proceedings, No.1, Cornell University, Ithaca, NY. 2008 Weerawardena, J. Exploring the role of market learning capability in competitive strategy". European Journal of Marketing, 2003, 37(3/4), 30-407. 